\title{
Pengaruh Penyuluhan Kesehatan Terhadap Pengetahuan Pencemaran Sampah Makroplastik Dan Mikroplastik Pada Mahasiswa Prodi D-III Perekam Dan Informasi Kesehatan Stikes Imelda
}

\author{
${ }^{1}$ Lamtiur Junita Bancin, ${ }^{2}$ Johanna Christy \\ Program Studi D-IV Manajemen Informasi Kesehatan, Universitas Imelda Medan
}

\begin{tabular}{l}
\hline \hline Article Info \\
\hline Article history: \\
Received August 4, 2020 \\
Revised August 29, 2020 \\
Accepted August 29, 2020
\end{tabular}

\section{Keywords:}

Knowledge

Plastic

Pollution

Macroplastic

Micro-plastic

\begin{abstract}
Health education is one of the techniques to increase someone's knowledge level due to the aim of improving knowledge and well understanding regarding microplastic and microplastic pollution. This research aimed to analyze the effect of health education towards the knowledge regarding macroplastic and microplastic pollution among students at the medical record and health major in the college of health sciences Imelda in terms of health education. Method This research used a quantitative approach with a Quasi-Experimental Study Design of a non-equivalent control group. The population was all the students with the medical record and health information major. The sampling technique used was purposive sampling, all the firstyear students. The group of the sample consisted of two groups- the intervention and the control group. The intervention group consisted of 73 people who have given health education. Control group consisted of 73 people who have not given any health education. The statistic test used was the Wilcoxon test. The statistic result on the knowledge variable among the experiment group who had a good knowledge level refer to the pre-test score only $4.1 \%$. After given health education, the increasing number of people who had a good knowledge level (76.1\%). The good knowledge level among the control group only showed $1.4 \%$ (pre-test and post-test). The result showed there was a significant increase after given health education among the experiment group $(\mathrm{p}=0.00)$. However, another result showed there was no significant difference among the control group $(\mathrm{p}=1.00)$. Health education towards macroplastic and microplastic pollution had a significant influence to the knowledge level for students. It is recommended for further research to examine the role of knowledge towards attitudes and behaviors or actions in the management of macro and microplastic waste pollution. Based on the results of the pre-test where respondents still have less and moderate knowledge while the issue of plastic waste in Indonesia requires full attention and more participation from the community from society, it is necessary to get the attention of educational institutions to further elaborate and educate students in pollution macro-plastic and microplastic waste.
\end{abstract}

This is an open access article under the CC BY-SAlicense.

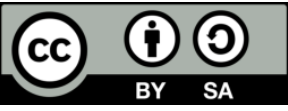

\footnotetext{
Corresponding Author:

Lamtiur Junita Bancin,

Program Studi D-IV Manajemen Informasi Kesehatan,

Universitas Imelda Medan,

Jl. Bilal No. 52 Kelurahan Pulo Brayan Darat I Kecamatan Medan Timur, Medan - Sumatera Utara.

Email : lamtiurjunitabancin@yahoo.com
} 


\section{PENDAHULUAN}

Masalah pencemaran plastik adalah masalah global yang tersebar di seluruh lautan di dunia. Jumlah produksi sampah plastik meningkat seiring dengan jumlah populasi didunia yang aktif menggunakan plastik dalam kehidupan sehari-hari (UNEP., 2017; Eriksen et al., 2014). Berdasarkan Our World in Data (2017), peningkatan produksi terjadi secara drastis dalam kurun waktu 65 tahun dari 1950 ( 2 juta ton per tahun) hingga 2015 (381 juta ton per hari). Masalah global tersebut juga menjadi isu di Indonesia karena penggunaan plastik yang tinggi tidak diiringi dengan waste management yang baik maka terjadi penimbunan dan akumulasi sampah yang tinggi dan berdampak hingga ke lautan.

Pada gambar 1, Indonesia pada tahun 2025 di prediksi sebagai negara ke-dua setelah China dengan kondisi mismanaged plastic waste yang diindikasikan dari jumlah sampah plastik yang masuk kelautan berisiko tinggi (Jambeck, 2015).

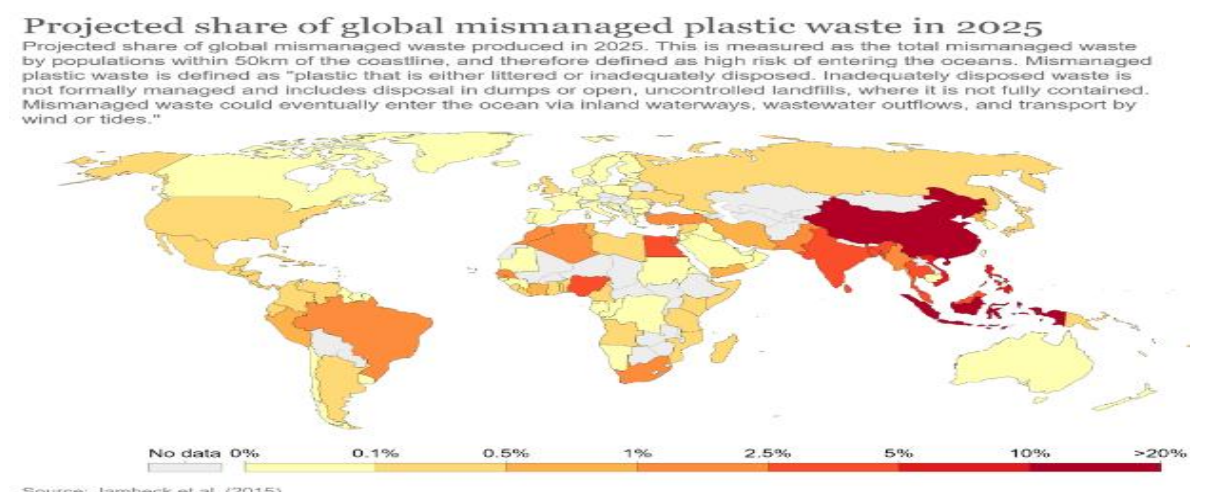

Gambar 1. Projected Share of Global Mismanaged Plastic Waste in 2025

Source: Jambeck et al, 2015

Berdasarkan penelitian dari (Lebreton, 2017) menunjukkan bahwa 4 dari 20 sungai teratas di dunia dengan kontribusi sampah plastik terbesar di dunia berasal dari Indonesia yaitu sungai Brantas, Solo, Progo, dan Serayu. Kondisi tersebut membutuhkan pola penanganan sampah plastik yang lebih serius. Jika tidak, kondisi tersebut bisa membahayakan manusia itu sendiri, dimana rasio ikan dan plastik di laut sudah berbanding 1:1 (lihat gambar 2).

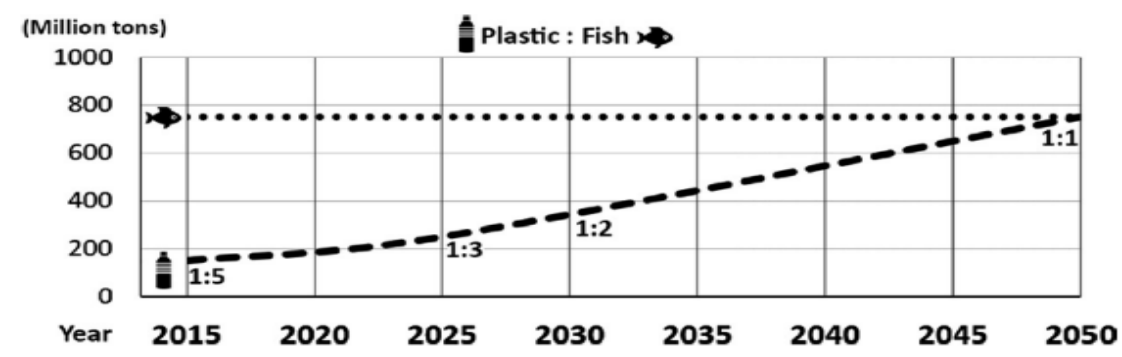

Gambar 2. Prediksi Rasio Ikan dan Plastik di Laut

Sumber: Christoper dan Brian, 2017

Selain membahayakan habitat laut, kondisi fatal tersebut juga mengancam ketahanan pangan di laut. Sampah plastik bisa tahan hingga puluhan tahun dan berdegradasi menjadi ukuran lebih kecil (mikroplastik). Ukuran lebih kecil tersebut tentu saja lebih memudahkan ikan secara tidak sengaja untuk mengonsumsinya. Melihat prediksi rasio ikan dan plastik di laut 1:1, maka kondisi tersebut akan menjadi potensi manusia mengonsumsi ikan yang secara tidak sengaja telah memakan mikroplastik. 
Di Indonesia tahun 2018, ikan paus di Wakatobi pernah mati terdampar karena memakan plastik dengan berat sekitar 5-6 kilogram. Jika kondisi sampah ini terus berlangsung, maka akan banyak spesies laut yang terdampak. Plastik sendiri memiliki karakteristik yang ringan dan mudah didapatkan. Penggunaan plastik dengan pemakaian sekali pakai sangat tinggi di Indonesia. Ada beberapa jenis plastik berdasarkan tipe polimernya seperti: Polyethylene yang dapat dijumpai pada botol plastic sekali pakai, plastik kresek, botol shampoo, dan lainnya. Polyprophylene yang dapat kita jumpai pada bungkus cemilan, wadah plastic yang tahan di microwave, tutup botol dan lainnya. Polystyrene yang masih digunakan pada wadah makanan (UNEP, 2019).

Masing-masing plastik mengandung bahan kimia masing-masing. Ada styrene pada plastik jenis polystyrene, bisphenol A dan ftalat yang menjadi bahan pada mainan anakanak dan jenis plastik lainnya. Jika kandungan zat tersebut di lepaskan atau release maka akan dapat membahayakan kesehatan manusia saat berakumulasi pada jangka waktu yang lama (kronis) (Andaluri, et al, 2018). Penelitian dari (Jurewicz, 2011) menunjukkan ada level asosiasi yang tinggi dari paparan ftalat terhadap resiko alergi dan asma. Paparan BPA memiliki potensi mengganggu hormon endokrin (Siracusa, 2018) Kandungan lain sperti BPA dapat dideteksi dalam darah wanita hamil, cairan amnion, jaringan plasenta, dan tali pusat yang menunjukkan terjadinya paparan pada janin. Setelah masuk ke dalam tubuh lewat saluran cerna, BPA dengan cepat berikatan dengan asam glukuronat menjadi BPA-glukuronida (Ilmiawati, 2017).

Berdasarkan data yang dimuat pada lama Sustainable Waste Indonesia (SWI) tahun 2017, hanya 7 persen sampah plastik di Indonesia yang didaur ulang, sementara 69 persen di antaranya menumpuk di tempat pembuangan akhir (TPA) dan 24 persen sisanya dibuang sembarangan dan mencemari lingkungan sehingga dikategorikan sebagai illegal dumping. Akumulasi sampah tanpa penanganan dan kesadaran masyarakat untuk mengurangi konsumsi sampah plastik akan mendorong penimbunan sampah plastik. Pencemaran sampah dalam laut merupakan permasalahan yang perlu mendapat perhatian penuh untuk dihadapi karena juga menjadi faktor utama permasalahan pencemaran di laut Indonesia. Laut dilindungi untuk mendukung pembangunan berkelanjutan, memecahkan masalahmasalah yang ada saat ini dan untuk keberlangsungan kehidupan di masa depan. Jika akumulasi sampah plastik mencapai lautan tetap dibiarkan, maka manusia memiliki potensi untuk mengkonsumsi plastik dari ikan yang memakan plastik tersebut. Sampah ini sendiri berasal dari aktivitas manusia yang menggunakan plastik. Permasalahan sampah di laut Indonesia dapat melibatkan beberapa faktor penyebab, yang salah satunya adalah budaya kesadaran (Ningsih, 2018).

Kesadaran masyarakat tersebut sejalan dengan kesadaran akan konsumsi plastik yang perlu diminimalisir. Untuk mencapai kesadaran tersebut pentingnya diberikan pengetahuan melalui penyuluhan kesehatan untuk menstimulasi sikap seseorang dalam mengambil tindakan pengendalian konsumsi plastik untuk meminimalisir akumulasi sampah plastic (Muis, 2018). Penyuluhan kesehatan perlu dilakukan untuk menanamkan keyakinan, pengetahuan dan kesadaran sehingga mampu melakukan suatu anjuran berkaitan dengan kepentingan kesehatan masyarakat yang dalam hal ini adalah plastic (SWI, 2017).

Pengetahuan tentang pencemaran sampah makroplastik mikroplastik perlu disebarluaskan melalui promosi kesehatan penyuluhan mengingat pengendalian terhadap plastik yang masih minim dan mampu membantu pemerintah dalam melaksanakan program pengendalian plastik. Penyuluhan merupakan salah satu metode mengedukasi masyarakat dengan meningkatkan pengetahuan agar masyarakat memiliki kesadaran untuk mengambil peran terhadap pengendalian sampah sejak dini yaitu mengurangi konsumsi penggunaan plastik sekali pakai. 


\section{METODE}

Jenis penelitian ini merupakan penelitian kuantitatif dengan menggunakan rancangan penelitian metode desain penelitian Quasi Experimental Study dengan rancangan nonequivalent control group design. Populasi Penelitian adalah seluruh mahasiswa/i program studi D-III Perekam dan Informasi Kesehatan yang berjumlah 363 orang. Sampel diambil secara purposive sampling yaitu seluruh mahasiswa tingkat 1 prodi D3 Perekam dan Informasi Kesehatan. Jumlah sampel pada penelitian ini terdiri dari dua kelompok:

1. Kelompok intervensi yaitu kelompok mahasiswa yang diberikan penyuluhan kesehatan sebanyak 73 orang.

2. Kelompok kontrol yaitu kelompok mahasiswa yang tidak diberikan penyuluhan kesehatan sebanyak 73 orang.

Tujuan penelitian ini untuk menganalisis pengaruh penyuluhan kesehatan terhadap pengetahuan mahasiswa/i Tingkat 1 Prodi Perekam dan Informasi Kesehatan, STIKes Imelda Medan, tentang pencemaran sampah makro plastic dan mikroplastik dalam upaya edukasi kesehatan.

1. Kegiatan pre-test pada kelompok intervensi dan kelompok kontrol, dilaksanakan seminggu sebelum intervensi.

2. Kelompok intervensi diberikan penyuluhan.

Tabel 1. Distribusi karakteristik demografi

\begin{tabular}{|c|c|c|c|}
\hline \multirow{2}{*}{$\frac{\text { Variabel }}{\text { Usia; rerata } \pm \text { SD }}$} & \multicolumn{2}{|c|}{ Kelompok } & \multirow{2}{*}{$\frac{\mathbf{P}(\mathbf{C I}: \mathbf{9 5 \%})}{0.000^{*}}$} \\
\hline & $\begin{array}{c}\text { Kontrol } \\
19,07 \pm 1,058\end{array}$ & $\begin{array}{c}\text { Eksperimen } \\
18.79 \pm 0,81\end{array}$ & \\
\hline \multicolumn{4}{|l|}{ Kategori usia; n (\%) } \\
\hline 18 & $22(30,1 \%)$ & $24(32,8 \%)$ & \\
\hline 19 & $32(43.8 \%)$ & $37(50,7 \%)$ & \\
\hline 20 & $19(26.1 \%)$ & $12(16,5 \%)$ & $0.000 *$ \\
\hline \multicolumn{4}{|l|}{ Jenis Kelamin;n(\%) } \\
\hline Perempuan & $55(75.3 \%)$ & $54(73,9 \%)$ & \\
\hline Laki-laki & $18(24.7 \%)$ & $19(26,1 \%)$ & $0,000 *$ \\
\hline \multicolumn{4}{|l|}{ T. Tinggal ; n $(\%)$} \\
\hline Medan & $16(21.9 \%)$ & $19(26.0 \%)$ & \\
\hline Deli Serdang & $6(8.2 \%)$ & $5(6.8 \%)$ & \\
\hline Pematangsiantar & $3(4.1 \%)$ & $1(1.4 \%)$ & \\
\hline Tapanuli & $9(12.3 \%)$ & $2(2.7 \%)$ & $0,015^{*}$ \\
\hline Padangsidimpuan & $9(12.3 \%)$ & $2(2.7 \%)$ & \\
\hline Nias & $17(23,3 \%)$ & $16(21,9 \%)$ & \\
\hline Labuhan Batu & $3(4.1 \%)$ & $3(4.1 \%)$ & \\
\hline Pekanbaru & $0(0.0 \%)$ & $5(6.8 \%)$ & \\
\hline Lainnya & $10(13.7 \%)$ & $20(27.4 \%)$ & \\
\hline \multicolumn{4}{|c|}{ Pernah mendengar informasi } \\
\hline $\mathrm{Ya}$ & $73(100 \%)$ & $73(100 \%)$ & \\
\hline Tidak & $0(0.0 \%)$ & $0(0.0 \%)$ & \\
\hline
\end{tabular}

Pada tabel diatas Distribusi karakteristik demografi terdapat rerata usia pada kelompok eksperimen lebih rendah dari pada kelompok control. Dari hasil uji statistik didapatkan perbedaan yang bermakna antara rerata usia pada kedua kelompok tersebut. Berdasarkan kategori usia pada kelompok control, kategori usia yang terbanyak adalah kelompok usia $19(43.8 \%)$ tahun, sedangkan pada kelompok eksperimen, terbanyak adalah usia 19 tahun $(50.7 \%)$. 
Tabel 2. Sumber Informasi Tentang Pencemaran Sampah Makroplastik \& Mikroplastik Yang Diperoleh Respoden Kelompok Eksperimen Dan Kelompok Kontrol

\begin{tabular}{lccc}
\hline Sumber Informasi & \multicolumn{2}{c}{ Kelompok } & \multirow{2}{*}{$\mathbf{p}$} \\
\cline { 2 - 3 } & Kontrol & Eksperimen & \\
\hline Sosial Media & $57(78,1 \%)$ & $45(61,6 \%)$ & \multirow{2}{*}{0.002} \\
\cline { 1 - 3 } Pembelajaran Mata Kuliah & $15(20,5 \%)$ & $27(37,0 \%)$ & \\
\hline Teman & $1(1,4 \%)$ & $7(9,6 \%)$ & \\
\hline
\end{tabular}

Pada tabel 2 tampak sebagaian besar sumber informasi tentang pencemaran sampah makroplastik dan mikroplastik yang diperoleh responden pada kelompok control adalah social media $(78.1 \%)$ begitu juga dengan kelompok eksperimen (61.6\%). Hasil uji statistik menunjukkan terdapat perbedaan bermakna sumber informasi tentang pencemaran sampah makroplastik dan mikroplastik antara kelompok control dan eksperimen $(\mathrm{p}=0.002)$.

Tabel 3. Perbedaan Pengetahuan Sebelum dan SesudahPenyuluhan Pencemaran Sampah Makroplastik \& Mikroplstik

\begin{tabular}{|c|c|c|c|c|c|c|c|c|}
\hline \multirow{3}{*}{$\begin{array}{c}\text { Variabel } \\
\text { Pengetahuan }\end{array}$} & \multicolumn{8}{|c|}{ Kelompok } \\
\hline & \multicolumn{4}{|c|}{ Kontrol } & \multicolumn{4}{|c|}{ Eksperimen } \\
\hline & \multicolumn{2}{|c|}{ Sebelum } & \multicolumn{2}{|c|}{ Sesudah } & \multicolumn{2}{|c|}{ Sebelum } & \multicolumn{2}{|c|}{ Sesudah } \\
\hline & $\mathbf{F}$ & $(\%)$ & $\mathbf{F}$ & $\%$ & $\mathbf{F}$ & $\%$ & $\mathbf{F}$ & $\%$ \\
\hline Baik & 1 & 1.4 & 1 & 1.4 & 3 & 4.1 & 56 & 76.7 \\
\hline Sedang & 51 & 699 & 51 & 69.9 & 34 & 46.6 & 17 & 23.3 \\
\hline Kurang & 21 & 28.7 & 21 & 28.7 & 36 & 49.3 & 0 & 0.0 \\
\hline
\end{tabular}

Tabel 3, pengetahuan baik adalah responden yang mendapatkan nilai pada kuisioner lebih dari $75 \%$, pengetahuan sedang adalah nilai dari $40-75 \%$, dan kurang dengan nilai kurang dari $40 \%$ terlihat bahwa pada kelompok control saat pre-test terdapat 51 orang dengan pengetahuan sedang (69.9\%), dan begitu juga dengan post-test. Pada kelompok eksperimen saat pre-test, terdapat 36 orang dengan pengetahuan kurang $(49.3 \%)$ kemudian setelah dilakukan penyuluhan, terdapat 56 orang dengan pengetahuan baik $(76.7 \%)$.

Tabel 4. Distribusi Beda Rerata Selisih Nilai Pre-Test Dan Nilai Post-Test

\begin{tabular}{lllll}
\hline No & Variabel Pengetahuan & Mean & Mean Perbedaan & $p$ \\
\hline 1 & Nilai Pretest & 44.16 & \multirow{2}{*}{19.58} & 0.00 \\
\hline 2 & NilaiPost-test & 64.01 & & \\
\hline
\end{tabular}

Positive rank: 73

Dari tabel 4 diatas dapat dilihat bahwa terdapat perbedaan antara sebelum dan sesudah penyuluhan terhadap pengetahuan $(p<0,05)$ dengan nilai positive rank yaitu 73 .

Tabel 5. PerbandinganPerbedaan Pengetahuan Sebelum dan Sesudah Penyuluhan

\begin{tabular}{|c|c|c|c|}
\hline Variabel & \multicolumn{2}{|c|}{ Kelompok } & $P(C I: 95 \%)$ \\
\hline $\begin{array}{c}\text { Pengetahuan; Rerata } \pm \\
\text { SD }\end{array}$ & $\begin{array}{c}\text { Kontrol } \\
\text { Rerata } \pm \text { SD }\end{array}$ & $\begin{array}{l}\text { Eksperimen } \\
\text { Rerata } \pm \text { SD }\end{array}$ & \\
\hline Pre-test & $47.29 \pm 16.05$ & $41.04 \pm 15.25$ & 0.000 \\
\hline Post-test & $47.29 \pm 16.05$ & $80.74 \pm 12.00$ & 0.000 \\
\hline
\end{tabular}

Pada tabel 5, terlihat bahwa terjadi peningkatan rerata pengetahuan pada kelompok eksperimen yang mendapat penyuluhan tentang pencemaran sampah makroplastik dan 
mikroplastik. Hasil uji static menunjukkan terdapat perbedaan yang bermakna sebelum dan setelah dilakukan penyuluhan pada kelompok eksperimen $(\mathrm{p}=0.00)$.

\section{PEMBAHASAN}

Pada penelitian ini didapatkan bahwa seluruh responden pernah mendengar informasi tentang sampah makro dan mikroplastik. Pada penelitian ini, didapatkan data demografik kedua kelompok yang terdiri dari usia, jenis kelamin, dan tempat tinggal yang menunjukan perbedaan bermakna antara kedua kelompok tersebut. Selain itu, media informasi tentang pencemaran sampah makroplastik dan mikroplastik yang diperoleh responden juga menunjukan perbedaan bermakna.

Adapun perlakuan (intervensi) yang digunakan dalam penelitian ini adalah penyuluhan kesehatan, yang menggunakan media powerpoint. Penyuluhan kesehatan tersebut merupakan salah satu cara yang digunakan untuk menambah pengetahuan dan kemampuan seseorang melalui teknik belajar atau instruksi dengan tujuan mengubah atau mempengaruhi perilaku manusia secara individu, kelompok maupun masyarakat. Tujuan penyuluhan kesehatan tentang pencemaran sampah makroplastik dan mikroplastik adalah menginformasikan kepada mahasiswa-mahasiswi D3 Perekam dan Infromasi Kesehatan tentang pencemaran sampah makroplastik dan mikroplastik . Dengan demikian mahasiswamahasiswi D3 Perekam dan Infromasi Kesehatan akan menggunakan pengetahuan dari hasil penyuluhan tersebut untuk menumbuhkan kesadaran agar mencapai kesehatan yang lebih baik. Pengetahuan tentang pencemaran sampah makroplastik dan mikroplastik juga meningkatkan pemahaman tentang masalah yang terjadi di masyarakat. Hasil penelitian menunjukkan bahwa strategi penyuluhan yang tepat dalam peningkatan kesadaran mahasiswa-mahasiswi D3 Perekam dan Infromasi Kesehatan adalah melalui ceramah dengan audiovisual (Wunaini dan Nurhidayah, 2018). Penelitian lainnya diperoleh bahwa pendidikan kesehatan menggunakan media audiovisual efektif dalam peningkatan pengetahuan perilaku hidup bersih dan sehat (Mulyadi, 2018).

Media juga merupakan salah satu unsur berhasilnya suatu komunikasi yang efektif antara pihak satu dengan pihak yang lain. Media yang dipakai dalam intervensi penyuluhan pada mahasiswa mahasiswi D3 Perekam dan Infromasi Kesehatan adalah menggunakan media powerpoint. Penggunaan media dapat membantu dalam mengatasi banyak hambatan dalam pemahaman (Notoatmodjo, 2012).

Hasil penelitian ini didapat bahwa pada kelompok yang mendapat penyuluhan kesehatan (eksperimen) (76,7\%),terjadi peningkatan pengetahuan daripada kelompok yang tidak mendapatkan penyuluhan (kontol) $(69,9 \%)$. Diperoleh hasil terdapat perbedaan bermakna antara nilai pretest dan posttest.

Hal ini sesuai dengan fase-fase yang terjadi setelah mendapat penyuluhan kesehatan dimana tujuan dan hasil yang diharapkan dari penyuluhan kesehatan berupa penambahan pengetahuan, perubahan kebiasaan dan proses menyadarkan orang lain dalam berperilaku.

Dalam teori Benyamin Blum menyatakan bahwa pengetahuan atau kognitif merupakan domain yang sangat penting untuk terbentuknya tindakan seseorang. Dalam teori tersebut dijelaskan pula bahwa perilaku merupakan faktor terbesar kedua setelah faktor lingkungan yang mempengaruhi kesehatan individu atau masyarakat. Oleh sebab itu, dalam rangka membina kesehatan masyarakat, intervensi terhadap faktor perilaku sangat strategis. Selain itu, pengetahuan tentang suatu objek tertentu sangat penting bagi terjadinya perubahan perilaku yang merupakan proses yang sangat kompleks. Perilaku yang didasari oleh pengetahuan akan lebih baik daripada perilaku yang tidak didasari oleh pengetahuan. WHO juga mengungkapkan bahwa seseorang berperilaku tertentu disebabkan oleh pemikiran dan perasaan dalam bentuk pengetahuan, persepsi, sikap, kepercayaan, dan penilaian-penilaian seseorang terhadap objek. Dalam hal ini, dengan 
pemberian penyuluhan kesehatan maka pengetahuan akan bertambah sehingga praktik juga akan lebih baik

Penelitian ini juga sejalan dengan penelitian (Fauzi et al., 2019) dengan hasil Kegiatan penyuluhan Pengenalan dan Pemahaman Bahaya Pencemaran Limbah Plastik telah meningkatkan pengetahuan antara 65-80\%. Pada hasil penelitian yang dilakukan oleh Nurafiyani tahun 2010 tingkat pengetahuan masyarakat tentang sampah rumah tangga pada hasil post test kelompok eksperimen dan kelompok control terdapat hasil t hitung adalah 4,042 dan $\mathrm{P}$ 0,000 $(\mathrm{P}<5 \%)$, sehingga dapat dinayatakan terdapat perbedaan antara post-test kelompok eksperimen dan kelompok control.

\section{KESIMPULAN}

Berdasarkan hasil penelitian diketahui penyuluhan kesehatan berpengaruh terhadap tingkat pengetahuan mahasiwa-mahasiwi D-III Perekam dan Infromasi Kesehatan. Hal ini diketahui dari:

1. Tingkat pengetahuan setelah mendapat penyuluhan tentang Pencemaran Sampah Makroplastik dan Mikroplastik lebih tinggi daripada sebelum mendapat penyuluhan.

2. Tingkat pengetahuan yang mendapat penyuluhan tentang Pencemaran Sampah Makroplastik dan Mikroplastik lebih tinggi daripada yang tidak mendapat penyuluhan.

\section{SARAN/REKOMENDASI}

1. Berdasarkan temuan dari peneliti bahwa seluruh responden pernah mendengar informasi tentang pencemaran sampah ini, namun hanya sedikit yang berpengetahuan baik. Pengetahuan yang baik dapat mendorong seseorang berperilaku baik oleh karena itu disarankan untuk peneltiian selanjutnya dapat meneliti peran pengetahuan terdapat sikap maupun perilaku atau tindakan dalam pengelolaan pencemaran sampah makro dan mikroplastik.

2. Melihat dari hasil pre-test dimana responden masih memiliki pengetahuan yang kurang dan sedang sementara isu sampah plastic di Indonesia membutuhkan perhatian khusus dan partisipasi lebih dari masyarakat dari seluruh lapisan individu, maka perlu mendapat perhatian dari institusi Pendidikan untuk lebih mengelaborasi dan mengedukasi anak didik dalam pencemaran sampah makroplastik dan mikroplastik.

\section{UCAPAN TERIMA KASIH}

Ucapan terima kasih diberikan kepada sumber dana riset penelitian (Kemenristekdikti, Penelitian Dosen Pemula tahun anggaran 2019), responden, LPPM dan seluruh civitas akademik Universitas Imelda Medan serta semua pihak yang tidak dapat disebutkan satu per satu.

\section{REFERENCES}

Andaluri, G., Manickavachagam, M. \& Suri, R. Plastic toys as a source of exposure to bisphenol-A and phthalates at childcare facilities. Environmental Monitoring Assess 190: 65. https://doi.org/10.1007/s10661-017-6438-9, 2018.

Christopher and Brian., Microplastic pollutants. Pp 19-37, 2017. https://doi.org/10.1016/B978-0-12-809406-8.00002-5 
Erikka. Pengaruh Penyuluhan Kesehatan Terhadap Tingkat Pengetahuan, Sikap Dan Praktik Ibu Dalam Pencegahan Demam Berdarah Dengue Pada Anak. Semarang. 2012.

Fauzi, M., Efizon, D., Sumiarsih, E., Windarti, W., Rusliadi, R., Putra, I., \& Amin, B. Pengenalan dan pemahaman bahaya pencemaran limbah plastik pada perairan di Kampung Sungai Kayu Ara Kabupaten Siak. Unri Conference Series: Community Engagement, 1, 341-346. 2019. https://doi.org/10.31258/unricsce.1.341-346

Ilmiawati, C., Reza, M., Rahmatini, R., \& Rustam, E. Edukasi Pemakaian Plastik sebagai Kemasan Makanan dan Minuman Serta Risikonya terhadap Kesehatan pada Komunitas di Kecamatan Bungus Teluk Kabung, Padang. LOGISTA-Jurnal Ilmiah Pengabdian kepada Masyarakat, 1(1), pp 20-28, 2017.

Jambeck, J. R., Geyer, R., Wilcox, C., Siegler, T. R., Perryman, M., Andrady, A., ... \& Law, K. L. Plastic waste inputs from land into the ocean. Science, 347(6223), pp 768$771,2015$.

Jurewicz, J., Hanke, W. Exposure to phthalates: Reproductive outcome and children health. A review of epidemiological studies. IJOMEH 24, pp 115-141, 2011. https://doi.org/10.2478/s13382-011-0022-2

Lebreton, L., van der Zwet, J., Damsteeg, J. et al. River plastic emissions to the world's oceans. National Communication, 1561, 2017.

Muis, A., \& Hidayat, F. R.. Hubungan Perilaku Membuang Sampah dan Pengetahuan Pengolahan Sampah dengan Kejadian Diare pada Siswa Kelas IX di SMPN 36 Samarinda Seberang Kelurahan Rapak Dalam, 2018.

Mulyadi, M. I., Warjiman, W., \& Chrisnawati, C. Efektivitas Pendidikan Kesehatan Dengan Media Video Terhadap Tingkat Pengetahuan Perilaku Hidup Bersih Dan Sehat. Jurnal Keperawatan Suaka Insan (JKSI), 3(2), pp 1-9, 2018. Retrieved from http://journal.stikessuakainsan.ac.id/index.php/jksi/article/view/111.

Ningsih, R. W. Dampak Pencemaran Air Laut Akibat Sampah Terhadap Kelestarian Laut Di Indonesia, 2018.

Notoatmodjo, S. Promosi Kesehatan dan Perilaku Kesehatan. Jakarta: Rineka Cipta. 2012.

Nurafiyah.,Pengaruh Penyuluhan Tentang Sampah Rumah Tangga Terhadap Tingkat Pengetahuan Masyarakat RT 13 Serangan Kelurahan Notoprajan Kecamatan Ngampilan. Yogyakarta: Sekolah Tinggi Ilmu Kesehatan Aisyiyah, 2010.

Siracusa, J. S., Yin, L., Measel, E., Liang, S., \& Yu, X. Effects of bisphenol A and its analogs on reproductive health: A mini review. Reproductive toxicology, 79, 96-123, 2018 .

Sustainable Waste Indonesia. Menuju Indonesia Peduli Sampah. 2017. Diakses pada tanggal 03 Juli 2020. https://katadata.co.id/infografik/2019/12/10/menuju-indonesiapeduli-sampah 
UNEP,. Our planet is drowning in plastic pollution. 2017. Retrieved from : https://www.unenvironment.org/interactive/beat-plastic-pollution/

\section{BIOGRAPHIES OF AUTHORS}

\begin{tabular}{l|l} 
Lamtiur Junita bancin, Lamtiur JunitaBancin, Gelar Sarjana diperoleh dari \\
Universitas Sumatera Utara, Jurusan Ilmu Kesehatan Masyarakat Peminatan \\
Epidemiologi pada tahun 2015. Gelar Magister (Master of Science) diperoleh dari \\
Taipei Medical University, Jurusan Global Health and Development pada tahun 2018. \\
Saat ini aktif sebagai pengajar di Program Studi D-IV Manajemen Informasi Kesehatan \\
Universitas Imelda Medan.
\end{tabular}

